\title{
Speciation Study of L-ascorbic Acid and its Chelated Cu(II) \& Ni(II) Complexes: an Experimental and Theoretical Model of Complex Formation
}

\author{
Sujay Mahata ${ }^{a}$, Ishani Mitra ${ }^{a}$, Subhajit Mukherjee ${ }^{a}{ }^{\S}$, Venkata Pera Reddy B. ${ }^{a}$, Goutam Kr. Ghosh ${ }^{b}$, \\ Wolfgang Linert ${ }^{c}$ (D) and Sankar Ch. Moi ${ }^{\mathrm{a}, \star}$ (i) \\ ${ }^{a}$ Department of Chemistry, National Institute of Technology, Durgapur, Durgapur-713209, W.B., India \\ ${ }^{b}$ Department of Chemistry, Bankura University, Bankura-722155, WB, India.
}

${ }^{C}$ Institute of Applied Synthetic Chemistry, Vienna University of Technology, Getreidemarkt, 9/163 AC, A-1060 Vienna, Austria.

Received 24 May 2018, revised 13 September 2019, accepted 13 September 2019.

\begin{abstract}
Different species of $\mathrm{L}$-ascorbic acid and their corresponding complex formation ability with $\mathrm{Cu}(\mathrm{II})$ and $\mathrm{Ni}$ (II) metal ions in aqueous medium has been studied in the $\mathrm{pH}$ range from 2.0-12.5. The stability constants of different complexes of $\mathrm{Cu}(\mathrm{II})$ and $\mathrm{Ni}(\mathrm{II})$ with the bidentate ligand, L-ascorbic acid were determined theoretically using MINIQUARD software. Speciation of ligand and complex of $\mathrm{Cu}(\mathrm{II}) / \mathrm{Ni}$ (II) ascorbate were experimentally investigated by the titration method in solution within this pH range. Different $\mathrm{Cu}$ (II) and $\mathrm{Ni}$ (II)-L-ascorbic acid species percentages with variation of $\mathrm{pH}$ were calculated within the studied $\mathrm{pH}$ range with the help of another computer programs SIM and SPECIES. Different species distribution diagrams and the equilibria for the formation of the species were also investigated and at higher $\mathrm{pH}, \mathrm{ML2}$ species was found to be the major species in the case of both the metal complexes. All the theoretical possible structures of $\mathrm{Cu}$ (II) and $\mathrm{Ni}$ (II) complexes with L-ascorbic acid were optimized and square pyramidal and square planer geometry have been evaluated for $\mathrm{Cu}$ (II) and $\mathrm{Ni}$ (II) respectively by Gaussian09 software. Their corresponding HOMO-LUMO energy and reactivity parameters such as chemical hardness $(\eta)$, ionization potential $(I)$, electron affinity (A), electro negativity $(\chi)$, chemical potential $(\mu)$, electrophilicity index $(\omega)$ have been calculated in order to provide a better understanding of the electronic structure of complexes with the experimental results.
\end{abstract}

KEYWORDS

$\mathrm{Cu}(\mathrm{II})$ and $\mathrm{Ni}(\mathrm{II})$ complexes, ascorbic acid, molecular speciation, DFT, reactivity parameters.

\section{Introduction}

Different metal ions play an important role ${ }^{1}$ in our physiological system, particularly in the presence of biologically relevant molecules such as vitamins, proteins, peptides and different enzymes. These molecules exist in different structures and conformations at different $\mathrm{pH}$. Metal ions, particularly $\mathrm{Ca}(\mathrm{II})$, $\mathrm{Fe}(\mathrm{III}), \mathrm{Cu}(\mathrm{II}), \mathrm{Ni}(\mathrm{II})$ and $\mathrm{Mg}(\mathrm{II})$ govern the metabolic steps in our biological system. ${ }^{2-6}$ Ascorbic acid is an essential micronutrient for several biochemical roles. It acts as a cofactor for various enzymes involved in several processes like hydroxylation of collagen, conversion of dopamine to nor epinephrine and in tyrosine metabolism. ${ }^{7,8}$ Ironically, ascorbic acid is also a recognized pro-oxidant in vitro. Ascorbic acid with $\mathrm{Cu}$ or Fe have been used to persuade oxidation in lipids, proteins and DNA., ${ }^{9,10}$ Ascorbic acid may initiate oxidation by reducing $\mathrm{Cu}^{2+}$ to $\mathrm{Cu}^{+}$, which results in reducing hydrogen peroxide $\left(\mathrm{H}_{2} \mathrm{O}_{2}\right)$ to hydroxyl radicals. ${ }^{11}$ It has also been observed that both ascorbic acid and nickel sulphate affect the metabolic functions in humans by oral exposure. ${ }^{12}$ The oral route of absorption for both is via different parts of the human gastrointestinal tract where, a variation of the $\mathrm{pH}$ of the micro-environment exists.

Over the past few decades, chemical speciation has been an analytical tool of paramount importance in human natural science and in pharmacological medicine. The chemical forms and speciation of the micronutrients (like copper and nickel

* To whom correspondence should be addressed. E-mail: sankarmoi67@yahoo.com based) substantially decide their biological or physiological functions. $\mathrm{Cu}(\mathrm{II})$ and $\mathrm{Ni}(\mathrm{II})$ metal ions are related with several enzymes ${ }^{13}$ and any change in their abundance in our physiological systems, which leads to metabolic disorders. Thus, different complex species of these metals with biologically relevant molecules is significant. The identification and quantification of the chemical forms of the trace metals is essential to elucidate biological activities in physiological system. A speciation analysis for the interaction of the metal ions with prevalent biomolecules will enlighten us regarding the bonding behaviour and the bio-availability of the formed species in biological fluids. L-ascorbic acid has a unique behaviour in respect of its flexible nature of chelating to different metal ions with different geometry, particularly with $\mathrm{Ni}(\mathrm{II})$ and $\mathrm{Cu}(\mathrm{II})$ complexes (Fig.1) and have been considered for speciation studies along with structural modelling by Density functional theory (DFT). The aim of the current investigation is to explore the interaction of L-ascorbic acid with the metal ions $\left(\mathrm{Cu}^{2+}\right.$ and $\left.\mathrm{Ni}^{2+}\right)$ and consequently, the relative concentration of the various possible species at different $\mathrm{pH}$ solutions in vitro, which in turn will aid in comprehending similar interactions in physiological systems in vivo.

\section{Experimental}

\subsection{Instrument and Software}

Titration of metal salts and L-ascorbic acid mixtures with 


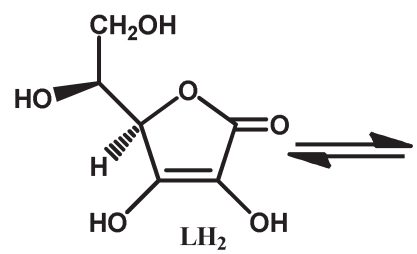<smiles>O=C1C(O)=C([OH2+])O[C@H]1[C@H](O)CO</smiles><smiles>C[C@]1([C@H](O)CO)O[C@H]([C@H](O)[18F])C(=O)C1=O</smiles>

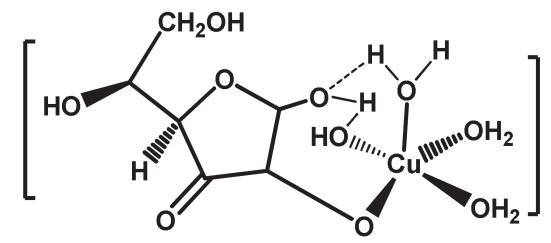

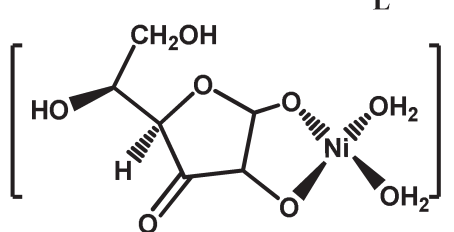<smiles>C[C@H](O)[C@H](C)O</smiles>

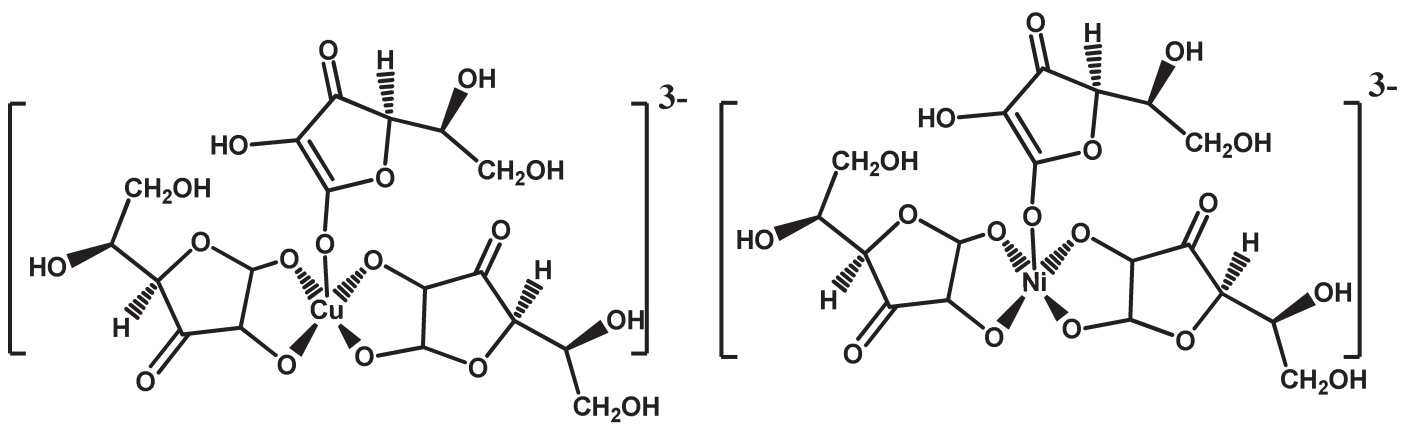

Figure 1 Various structures of L-ascorbic acid and its existing metal complexes $\left[\mathrm{ML}\left(\mathrm{H}_{2} \mathrm{O}\right)_{3}\right],\left[\mathrm{ML}_{2}\left(\mathrm{H}_{2} \mathrm{O}\right)\right]^{2-}$ and $\left[\mathrm{ML}_{3}\left(\mathrm{H}_{2} \mathrm{O}\right)\right]^{3-}($ where, $\mathrm{M}=\mathrm{Cu}(\mathrm{II}) / \mathrm{Ni}(\mathrm{II})$ metal ion complexes.

$0.386(\mathrm{M}) \mathrm{NaOH}$ were performed with variable concentration of metal ions and ligand by Metrohm 888-Titrando (Titroprocessor), which was standardized by $0.01(\mathrm{M})$ potassium hydrogen phthalate solution. SCPHD, MINIQUARD, SIM and SPECIES software programs were used for correction factor, stability constants and species percentage determination, respectively. DFT calculations were performed by Gaussian09 software ${ }^{14}$ with B3LYP level theory and 6-31G(d) basis set in polar continuum model using water as solvent.

\subsection{Reagents and Methods}

GR grade anhydrous $\mathrm{CuSO}_{4}(99.99 \%)$ and $\mathrm{NiCl}_{2}(99.99 \%)$ were purchased from Merck, India, and were used to prepare $\left(0.1 \mathrm{~mol} \mathrm{~L}^{-1}\right)$ aqueous solutions in double-distilled water. L-ascorbic acid $(99.0 \%)$ was purchased from Sigma Aldrich and aqueous $0.1(\mathrm{M})$ solution was prepared for speciation study in solution phase. $2.0 \mathrm{~mol} \mathrm{~L}^{-1}$ of titrant solution was prepared from $\mathrm{NaCl}(99.0 \%)$ (Merck, India). Various errors (liquid junction potential, $\mathrm{Na}^{+}$ion, activity coefficient, etc.) and correction factors were calculated from simulated acid-base titration data and computed by the SCPHD program..$^{15,16}$ The reactions were monitored at constant temperature $25 \pm 0.1{ }^{\circ} \mathrm{C}$ throughout the titration process using temperature thermostat. For all the titrations, the mixed titrants contain $0.1-0.2 \mathrm{~m} . \mathrm{mol}$ of hydrochloric acid out of $50.0 \mathrm{~cm}^{3}$ solutions. Relative concentrations of metal ions and chelating ligand 1:1, 1:2, 1:3 and 1:4 were taken respectively in $50 \mathrm{~mL}$ volume and titrated with standard $\mathrm{NaOH}$ solution. Triplicate titrations were repeated to achieve best results for each stoichiometric ratio of different metal ligand combinations. Different reaction conditions, concentrations and calculated stability constant $(\log \beta)$ values for different complex species of $\mathrm{Cu}(\mathrm{II})$ and $\mathrm{Ni}(\mathrm{II})$ ions with L-ascorbic acid are shown in Tables 1 and 2 .

\subsection{Modelling of Complex Species}

Complex formation stability constant of different probable complexes, a best fitting metal chelates with different stoichiometric ratio of metal and ligand were considered and calculated by SIM computer program. ${ }^{17}$ Few heuristics were performed to refine the $\log \beta$ and validate the models. ${ }^{18,19}$ Formation constant of acid-base equilibria of metal complex formation of both $\mathrm{Ni}$ (II) and $\mathrm{Cu}(\mathrm{II})$ of L-ascorbic acid were selected based on possibility and refinement of stability constant, which were calculated by SIM computer program. Their structures were optimized by Gaussian09 software B3LYP/6-31G(d) in CPCM-water.

Table 1 Calculated stability constant $(\log \beta)$ values for different complex species of $\mathrm{Cu}(\mathrm{II})$ ion with $\mathrm{L}$-ascorbic acid.

cu2aadm.txt

No. of complexes $=7$

\begin{tabular}{|c|c|}
\hline No. of expt. $=3$ & No. of ligands $=1$ \\
\hline $\log \beta \quad$ and & M L H values \\
\hline 11.361 & $\begin{array}{lll}0 & 1 & 1\end{array}$ \\
\hline 15.221 & $\begin{array}{lll}0 & 1 & 2\end{array}$ \\
\hline 21.513 & $\begin{array}{lll}1 & 1 & 0\end{array}$ \\
\hline 24.036 & $\begin{array}{lll}1 & 1 & 1\end{array}$ \\
\hline 24.488 & $\begin{array}{lll}1 & 1 & 2\end{array}$ \\
\hline 35.664 & 122 \\
\hline-13.900 & $\begin{array}{llll}0 & 0 & -1\end{array}$ \\
\hline
\end{tabular}


Table 2 Different reaction conditions and calculated stability constant $(\log \beta)$ values for different complex species of Ni(II) ion with L-ascorbic acid at $25^{\circ} \mathrm{C}$ temperature.

Abbreviations: M:L:H = 1:1:1

indicates as one metal ion: one ligand; one proton; $\mathrm{FM}$ = free metal ion

\begin{tabular}{|c|c|c|c|}
\hline \multicolumn{4}{|c|}{$\begin{array}{l}\text { MODEL } 1 \text { fltrniaa.txt } \\
\text { TEMP }=25.0^{\circ} \mathrm{C}\end{array}$} \\
\hline FORMA & ON REF & INEMENT & STOICHIOMETRIC \\
\hline CONST & NTS & KEYS & COEFFICIENT \\
\hline (1) & 11.4914 & 3.1001E 11 & $\begin{array}{lll}1 & 1 & 1\end{array}$ \\
\hline (2) & 15.0050 & 1.0116E 15 & 12 \\
\hline (3) & -13.9000 & $0.1259 \mathrm{E}-13$ & $\begin{array}{lll}0 & 0 & -1\end{array}$ \\
\hline
\end{tabular}

Abbreviations: M:L2:H2 = 1:2:2

indicates as one metal ion: two ligands: two protons; FL = free ligand

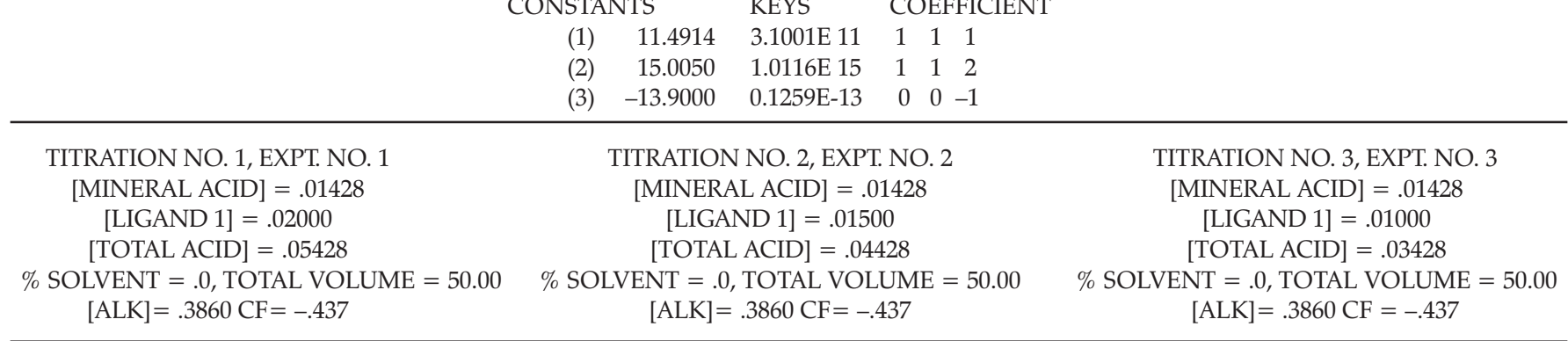

\section{Results and Discussion}

The outcome of different reaction conditions and stability constant $(\log \beta)$ values for different complex species for the best-fit models were calculated with 'MINIQUARD' software program and given in Tables 1 and 2 . Lower standard divergence in the $\log \beta$ signifies the precision of these parameters, which effect the formation constant. The experimental results can be represented by the model species where small values of $U_{\text {corr }}$ (summation of the squares of the change in the concentrations of different species at all the points) correspond to the correction for degrees of freedom. The lesser values of the mean, mean deviation and standard deviation substantiate that the residuals are about a zero mean with little variation which is a part of a normal statistical distribution. Therefore, applying least squares method in the current results and obtained statistical parameters describe the best-fit models of the $\mathrm{Ni}(\mathrm{II})$ and $\mathrm{Cu}(\mathrm{II})$ with $\mathrm{L}$-ascorbic acid chelation in aqueous medium.

\subsection{Species Distribution Diagrams}

Probable different species formation of L-ascorbic acid with $\mathrm{Ni}(\mathrm{II})$ and $\mathrm{Cu}$ (II) complexes are shown in Scheme 1. pKa values of L-ascorbic acid are evaluated from calculated stability constant $(\log \beta)$ followed by different species formation within the studied $\mathrm{pH}$ range, which are found to be very close to the reported ${ }^{20} \mathrm{pKa}$ values (4.04 and 11.7) of L-ascorbic acid. It also indicates the precession and reliability of the methods. Ascorbic acid possesses three potential functional groups (vinyl $\mathrm{OH}$, alcoholic- $\mathrm{OH}$ and carboxylic acid (-COOH) group) but only the vinyl $\mathrm{OH}$ group participates in de-protonation equilibrium and takes part in the complex formation reaction either through two vicinal oxygen centres or single oxygen centre as shown in Fig. 1. The neutral and deprotonated form of $\mathrm{L}$-ascorbic acid remain as $\mathrm{LH}_{2}, \mathrm{LH}^{-}$and $\mathrm{L}^{2-}$ in the following $\mathrm{pH}$ ranges from 2.0-5.0, 2.0-10.0 and 10.0-12.0 (where, $\mathrm{L}=$ bidentate or monodentate $\mathrm{L}$-ascorbic acid). Ascorbic acid is a reductone, having a carbonyl group adjacent to the enediol moiety, i.e. $-\mathrm{C}(\mathrm{OH})=\mathrm{C}(\mathrm{OH})$ $\mathrm{C}=\mathrm{O})$-. After successive deprotonation of both these hydroxyl groups, it forms a resonance stabilized bay region, an electron rich reactive zone which reveals five-membered ring chelations with metal ions. Other hydroxyl groups on the side chain do not deprotonate in this working $\mathrm{pH}$ range. Furthermore, enediol structure is stabilized by the resonance in consequence of tautomerism with the adjacent carbonyl.

Species formation of L-ascorbic acid with variation of $\mathrm{pH}$ is also confined by potentiometric titration with standard base in the $\mathrm{pH}$ range $2.0-12.0$ (Fig. $2 \mathrm{~A}$ ). The stability constants of all possible species were determined by computational program

SIM and shown in (Tables 1 and 2). Different percentage of species of both metal complexes ${ }^{20}$ with variation of $\mathrm{pH}$ were calculated using SIM software and shown in (Tables 3 and 4). The species distribution diagram of metal ions $\mathrm{Ni}(\mathrm{II})$ and $\mathrm{Cu}(\mathrm{II})$ form different species ${ }^{21,22}$ with L-ascorbic acid are shown in (Fig. $2 \mathrm{C}$ and Fig. 2B).The probable metal-ligand complexes are $\mathrm{ML}_{2}$, $\mathrm{MLH}^{+}$and $\mathrm{ML}_{2} \mathrm{H}$, (where, $\mathrm{M}=\mathrm{Cu}(\mathrm{II}) / \mathrm{Ni}$ (II) ions and $\mathrm{L}=$ L-ascorbic acid) which are shown in Figs 1 and 2. The species distribution diagrams of binary systems were plotted $\mathrm{pH}$ versus $\%$ of different species formed at a particular $\mathrm{pH}$ and were performed using software SIM and Origin-8. These equilibria for the formation different species of ascorbic acid and their different complex formation in aqueous in the studied $\mathrm{pH}$ ranges can be represented as follows:

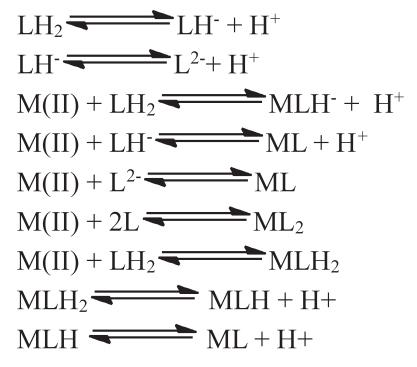

Scheme 1

Equilibria for the formation of different species of ascorbic acid and its complexes with metal in aqueous medium.

In the case of $\mathrm{Cu}(\mathrm{II})$, complex species $\left(\mathrm{MLH}_{2}\right)$ forms below $\mathrm{pH}$ 2.0 and species percentage reaches maximum $15 \%$ and starts to decrease and becomes zero at $\mathrm{pH}$ 2.3. Similarly complex MLH remains at $30 \%$ at pH 2.0 and at 4.0, becomes zero. Complex 1, species ML was at $55 \%$ at $\mathrm{pH} 2.0$ and became maximum $(100 \%)$ at $\mathrm{pH}$ 3.0-6.0 and decreased. Simultaneously $\mathrm{ML}_{2}$, the corresponding species for complex 2 started to form and increased with the increase of $\mathrm{pH}$ up to 12.0. No complex 3 species ML3 was traced out in the experimental speciation diagram. A similar observation was found in case of $\mathrm{Ni}$ (II) complexes with different species percentage as shown in Fig. 2C.

\subsection{Structural Optimization and Theoretical Evidence on Experimental Results}

Experimentally determined $\mathrm{Cu}(\mathrm{II}) / \mathrm{Ni}(\mathrm{II})$ complexes with L-ascorbic acid as different species formation with variation of $\mathrm{pH}$ were confirmed by density functional theory (DFT) study. The predominating complexes like $\mathrm{ML}, \mathrm{ML}_{2}$ were found in species diagram and their formation were supported by density 


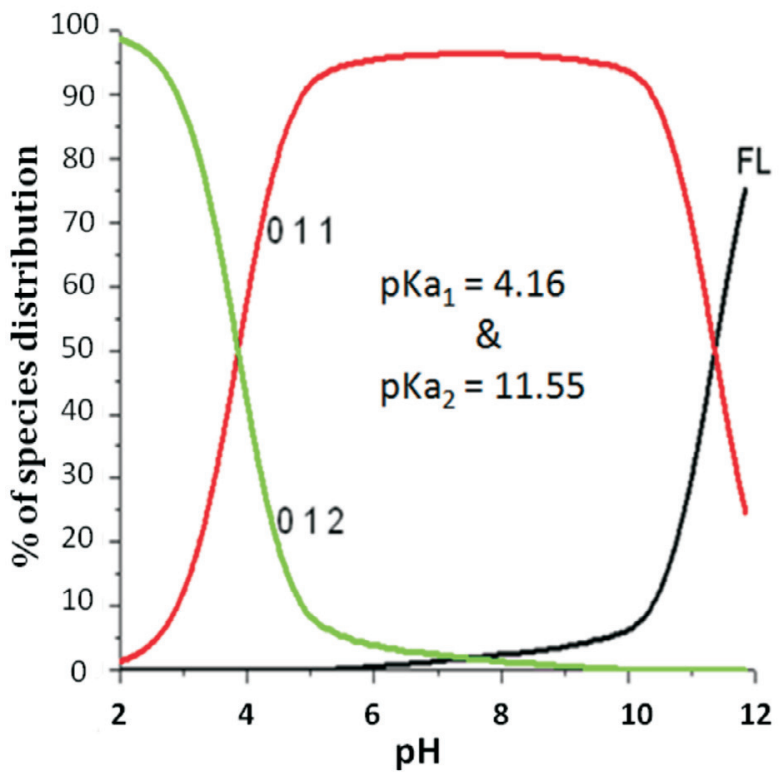

A
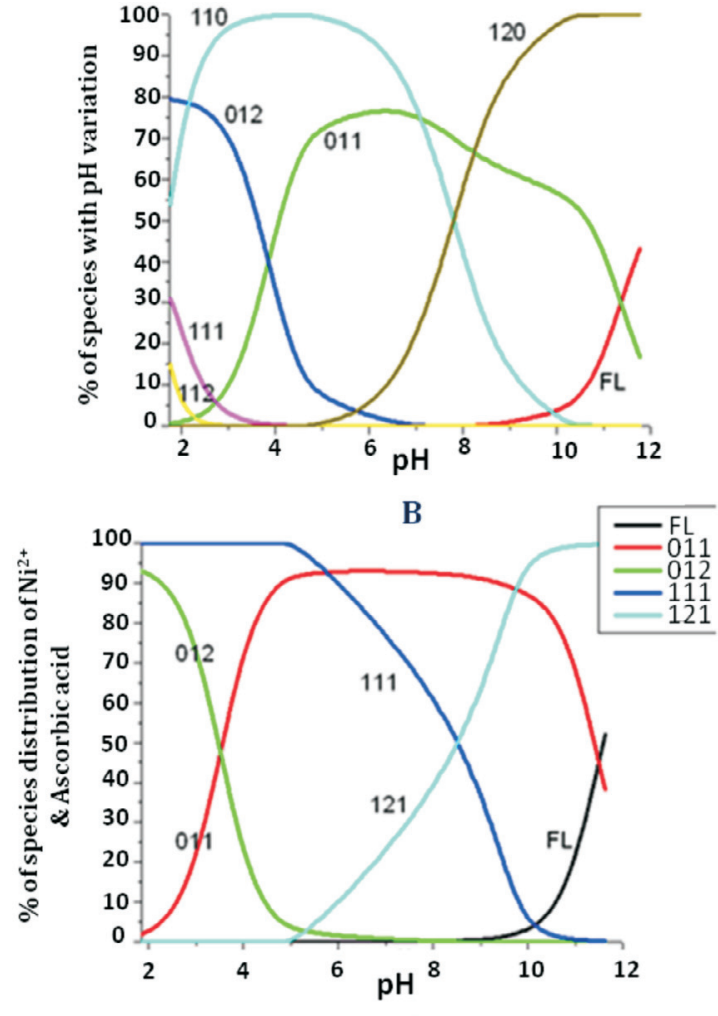

C

Figure 2 Species distribution diagram of (A) L-ascorbic acid, (B) $\mathrm{Cu}$ (II)-ascorbic acid complexes, and (C) $\mathrm{Ni}$ (II)-ascorbic acid complexes

functional theory (DFT) also. Structural parameters like bond distance $(\AA)$ and bond angles $\left({ }^{\circ}\right)$ of different possible $\mathrm{Cu}(\mathrm{II}) / \mathrm{Ni}(\mathrm{II})$ complexes were calculated and determined from optimized structures, which are shown in Fig 3. Generally, $\mathrm{Cu}$ (II) ions form different structural complexes having octahedral, square planar and distorted square pyramidal geometry with bidente ligand $(\mathrm{O}, \mathrm{O}$ donor). More stable theoretically found $\mathrm{Cu}(\mathrm{II})$ complexes like $\left[\mathrm{Cu}\left(\mathrm{L}\right.\right.$-asa) $\left.\left(\mathrm{H}_{2} \mathrm{O}\right)_{3}(\mathrm{OH})\right] \mathbf{1}$ (species $\mathrm{ML}$ ), $\left[\mathrm{Cu}(\mathrm{L}-\mathrm{asa})_{2}\left(\mathrm{H}_{2} \mathrm{O}\right)_{2}\right]^{2-} \mathbf{2}$ (species $\mathrm{ML}_{2}$ ) and $\left[\mathrm{Cu}(\mathrm{L} \text {-asa) })_{4}\right]^{2-} 3$ (species $\mathrm{ML}_{3}$ ) reveal square pyramidal geometry other than octahedral or square planar. In Table $3 \mathrm{Cu}(\mathrm{II})$-ascorbic acid species distribution with variation of $\mathrm{pH}$ in aqueous medium.

\begin{tabular}{|c|c|c|c|c|c|c|c|c|c|c|c|c|c|c|c|c|c|}
\hline \multicolumn{18}{|c|}{ Species distribution $(\%)$ of cupper L-ascorbate complex } \\
\hline $\mathrm{pH}$ & FM & FL & 011 & 012 & 110 & 111 & 112 & 120 & $\mathrm{pH}$ & FM & FL & 011 & 012 & 110 & 111 & 112 & 120 \\
\hline 1.767 & .00 & .00 & .64 & 79.36 & 53.74 & 31.10 & 15.16 & .00 & 3.589 & .00 & .00 & 27.91 & 52.09 & 99.13 & .86 & .01 & .00 \\
\hline 1.787 & .00 & .00 & .67 & 79.33 & 55.27 & 30.53 & 14.20 & .00 & 3.751 & .00 & .00 & 35.01 & 44.99 & 99.40 & .60 & .00 & .00 \\
\hline 1.808 & .00 & .00 & .70 & 79.30 & 56.84 & 29.91 & 13.25 & .00 & 3.912 & .00 & .00 & 42.39 & 37.61 & 99.58 & .41 & .00 & .01 \\
\hline 1.830 & .00 & .00 & .74 & 79.26 & 58.46 & 29.23 & 12.31 & .00 & 4.081 & .00 & .00 & 49.94 & 30.06 & 99.71 & .28 & .00 & .01 \\
\hline 1.853 & .00 & .00 & .78 & 79.22 & 60.12 & 28.50 & 11.38 & .00 & 4.270 & .00 & .00 & 57.60 & 22.40 & 99.80 & .18 & .00 & .02 \\
\hline 1.877 & .00 & .00 & .82 & 79.18 & 61.82 & 27.72 & 10.47 & .00 & 4.509 & .00 & .00 & 65.33 & 14.66 & 99.85 & .10 & .00 & .05 \\
\hline 1.903 & .00 & .00 & .87 & 79.13 & 63.57 & 26.87 & 9.57 & .00 & 4.886 & .00 & .00 & 73.09 & 6.89 & 99.84 & .04 & .00 & .12 \\
\hline 1.930 & .00 & .00 & .93 & 79.07 & 65.36 & 25.96 & 8.68 & .00 & 6.554 & .00 & .00 & 78.70 & .16 & 94.28 & .00 & .00 & 5.71 \\
\hline 1.959 & .00 & .00 & .99 & 79.01 & 67.20 & 24.98 & 7.82 & .00 & 7.726 & .00 & .02 & 71.01 & .01 & 55.19 & .00 & .00 & 44.81 \\
\hline 1.989 & .00 & .00 & 1.06 & 78.94 & 69.08 & 23.94 & 6.99 & .00 & 8.591 & .00 & .11 & 63.08 & .00 & 15.95 & .00 & .00 & 84.05 \\
\hline 2.022 & .00 & .00 & 1.14 & 78.86 & 71.00 & 22.82 & 6.18 & .00 & 10.124 & .00 & 3.29 & 56.83 & .00 & .61 & .00 & .00 & 99.39 \\
\hline 2.057 & .00 & .00 & 1.24 & 78.76 & 72.96 & 21.63 & 5.40 & .00 & 10.556 & .00 & 8.14 & 51.91 & .00 & .25 & .00 & .00 & 99.75 \\
\hline 2.095 & .00 & .00 & 1.35 & 78.65 & 74.97 & 20.37 & 4.66 & .00 & 10.788 & .00 & 12.66 & 47.37 & .00 & .16 & .00 & .00 & 99.84 \\
\hline 2.136 & .00 & .00 & 1.48 & 78.52 & 77.01 & 19.03 & 3.96 & .00 & 10.952 & .00 & 16.82 & 43.20 & .00 & .12 & .00 & .00 & 99.88 \\
\hline 2.181 & .00 & .00 & 1.64 & 78.36 & 79.09 & 17.61 & 3.30 & .00 & 11.080 & .00 & 20.61 & 39.41 & .00 & .10 & .00 & .00 & 99.90 \\
\hline 2.232 & .00 & .00 & 1.84 & 78.16 & 81.20 & 16.11 & 2.69 & .00 & 11.186 & .00 & 24.04 & 35.98 & .00 & .09 & .00 & .00 & 99.91 \\
\hline 2.288 & .00 & .00 & 2.08 & 77.92 & 83.33 & 14.53 & 2.13 & .00 & 11.277 & .00 & 27.11 & 32.91 & .00 & .08 & .00 & .00 & 99.92 \\
\hline 2.351 & .00 & .00 & 2.40 & 77.60 & 85.48 & 12.88 & 1.63 & .00 & 11.357 & .00 & 29.85 & 30.16 & .00 & .07 & .00 & .00 & 99.93 \\
\hline 2.424 & .00 & .00 & 2.83 & 77.17 & 87.64 & 11.16 & 1.20 & .00 & 11.427 & .00 & 32.28 & 27.73 & .00 & .06 & .00 & .00 & 99.94 \\
\hline 2.509 & .00 & .00 & 3.41 & 76.59 & 89.78 & 9.40 & .83 & .00 & 11.491 & .00 & 34.44 & 25.57 & .00 & .06 & .00 & .00 & 99.94 \\
\hline 2.611 & .00 & .00 & 4.27 & 75.73 & 91.86 & 7.61 & .53 & .00 & 11.548 & .00 & 36.36 & 23.65 & .00 & .06 & .00 & .00 & 99.94 \\
\hline 2.734 & .00 & .00 & 5.57 & 74.43 & 93.84 & 5.85 & .31 & .00 & 11.600 & .00 & 38.06 & 21.96 & .00 & .05 & .00 & .00 & 99.95 \\
\hline 2.883 & .00 & .00 & 7.63 & 72.37 & 95.61 & 4.23 & .16 & .00 & 11.648 & .00 & 39.56 & 20.45 & .00 & .05 & .00 & .00 & 99.95 \\
\hline 3.056 & .00 & .00 & 10.85 & 69.15 & 97.04 & 2.89 & .07 & .00 & 11.692 & .00 & 40.90 & 19.11 & .00 & .05 & .00 & .00 & 99.95 \\
\hline 3.240 & .00 & .00 & 15.47 & 64.53 & 98.06 & 1.91 & .03 & .00 & 11.732 & .00 & 42.10 & 17.91 & .00 & .05 & .00 & .00 & 99.95 \\
\hline 3.420 & .00 & .00 & 21.29 & 58.71 & 98.71 & 1.27 & .01 & .00 & 11.770 & .00 & 43.17 & 16.84 & .00 & .05 & .00 & .00 & 99.95 \\
\hline
\end{tabular}


Table $4 \mathrm{Ni}(\mathrm{II})$-L-ascorbic acid species distribution with variation of $\mathrm{pH}$ in aqueous medium.

\begin{tabular}{|c|c|c|c|c|c|c|c|c|c|c|c|c|c|}
\hline & & & & Speci & stributi & $\%$ ) of $N$ & (II) com & $x$ wit & -ascor & & & & \\
\hline $\mathrm{pH}$ & FM & FL & 011 & 012 & 111 & 121 & $\mathrm{pH}$ & $\mathrm{FM}$ & FL & 011 & 012 & 111 & 121 \\
\hline 1.806 & .00 & .00 & 1.83 & 93.17 & 100.00 & .00 & 3.670 & .00 & .00 & 55.96 & 39.04 & 100.00 & .00 \\
\hline 1.828 & .00 & .00 & 1.92 & 93.08 & 100.00 & .00 & 3.741 & .00 & .00 & 59.65 & 35.35 & 100.00 & .00 \\
\hline 1.851 & .00 & .00 & 2.02 & 92.98 & 100.00 & .00 & 3.815 & .00 & .00 & 63.36 & 31.64 & 100.00 & .00 \\
\hline 1.876 & .00 & .00 & 2.14 & 92.86 & 100.00 & .00 & 3.894 & .00 & .00 & 67.09 & 27.91 & 100.00 & .00 \\
\hline 1.902 & .00 & .00 & 2.27 & 92.73 & 100.00 & .00 & 3.980 & .00 & .00 & 70.82 & 24.18 & 100.00 & .00 \\
\hline 1.929 & .00 & .00 & 2.41 & 92.59 & 100.00 & .00 & 4.076 & .00 & .00 & 74.57 & 20.43 & 100.00 & .00 \\
\hline 1.957 & .00 & .00 & 2.57 & 92.43 & 100.00 & .00 & 4.186 & .00 & .00 & 78.33 & 16.67 & 100.00 & .00 \\
\hline 1.988 & .00 & .00 & 2.75 & 92.25 & 100.00 & .00 & 4.317 & .00 & .00 & 82.10 & 12.90 & 100.00 & .00 \\
\hline 2.020 & .00 & .00 & 2.96 & 92.04 & 100.00 & .00 & 4.487 & .00 & .00 & 85.87 & 9.12 & 99.99 & .01 \\
\hline 2.055 & .00 & .00 & 3.19 & 91.81 & 100.00 & .00 & 4.738 & .00 & .00 & 89.66 & 5.34 & 99.99 & .01 \\
\hline 2.092 & .00 & .00 & 3.47 & 91.53 & 100.00 & .00 & 5.292 & .00 & .00 & 93.44 & 1.56 & 99.96 & .04 \\
\hline 2.132 & .00 & .00 & 3.79 & 91.21 & 100.00 & .00 & 8.581 & .00 & .11 & 92.75 & .00 & 57.24 & 42.76 \\
\hline 2.175 & .00 & .00 & 4.16 & 90.84 & 100.00 & .00 & 9.666 & .00 & 1.33 & 89.18 & .00 & 10.29 & 89.71 \\
\hline 2.221 & .00 & .00 & 4.61 & 90.39 & 100.00 & .00 & 10.425 & .00 & 7.13 & 82.98 & .00 & 2.11 & 97.89 \\
\hline 2.271 & .00 & .00 & 5.14 & 89.86 & 100.00 & .00 & 10.592 & .00 & 10.09 & 79.99 & .00 & 1.50 & 98.50 \\
\hline 2.326 & .00 & .00 & 5.79 & 89.21 & 100.00 & .00 & 10.719 & .00 & 13.01 & 77.05 & .00 & 1.17 & 98.83 \\
\hline 2.386 & .00 & .00 & 6.58 & 88.42 & 100.00 & .00 & 10.822 & .00 & 15.88 & 74.17 & .00 & .96 & 99.04 \\
\hline 2.450 & .00 & .00 & 7.55 & 87.45 & 100.00 & .00 & 10.910 & .00 & 18.69 & 71.35 & .00 & .82 & 99.18 \\
\hline 2.519 & .00 & .00 & 8.74 & 86.26 & 100.00 & .00 & 10.986 & .00 & 21.44 & 68.59 & .00 & .72 & 99.28 \\
\hline 2.593 & .00 & .00 & 10.18 & 84.82 & 100.00 & .00 & 11.055 & .00 & 24.13 & 65.90 & .00 & .64 & 99.36 \\
\hline 2.670 & .00 & .00 & 11.91 & 83.09 & 100.00 & .00 & 11.117 & .00 & 26.75 & 63.28 & .00 & .58 & 99.42 \\
\hline 2.749 & .00 & .00 & 13.94 & 81.06 & 100.00 & .00 & 11.175 & .00 & 29.29 & 60.73 & .00 & .53 & 99.47 \\
\hline 2.828 & .00 & .00 & 16.26 & 78.74 & 100.00 & .00 & 11.228 & .00 & 31.76 & 58.26 & .00 & .49 & 99.51 \\
\hline 2.907 & .00 & .00 & 18.85 & 76.15 & 100.00 & .00 & 11.278 & .00 & 34.16 & 55.86 & .00 & .46 & 99.54 \\
\hline 2.984 & .00 & .00 & 21.66 & 73.34 & 100.00 & .00 & 11.325 & .00 & 36.47 & 53.55 & .00 & .43 & 99.57 \\
\hline 3.059 & .00 & .00 & 24.67 & 70.33 & 100.00 & .00 & 11.369 & .00 & 38.71 & 51.31 & .00 & .40 & 99.60 \\
\hline 3.131 & .00 & .00 & 27.84 & 67.16 & 100.00 & .00 & 11.411 & .00 & 40.85 & 49.16 & .00 & .38 & 99.62 \\
\hline 3.201 & .00 & .00 & 31.12 & 63.88 & 100.00 & .00 & 11.451 & .00 & 42.92 & 47.10 & .00 & .37 & 99.63 \\
\hline 3.270 & .00 & .00 & 34.50 & 60.50 & 100.00 & .00 & 11.489 & .00 & 44.90 & 45.12 & .00 & .35 & 99.65 \\
\hline 3.337 & .00 & .00 & 37.96 & 57.04 & 100.00 & .00 & 11.526 & .00 & 46.79 & 43.22 & .00 & .34 & 99.66 \\
\hline 3.403 & .00 & .00 & 41.48 & 53.52 & 100.00 & .00 & 11.561 & .00 & 48.60 & 41.41 & .00 & .32 & 99.68 \\
\hline 3.469 & .00 & .00 & 45.05 & 49.95 & 100.00 & .00 & 11.595 & .00 & 50.33 & 39.69 & .00 & .31 & 99.69 \\
\hline 3.535 & .00 & .00 & 48.66 & 46.34 & 100.00 & .00 & 11.627 & .00 & 51.97 & 38.04 & .00 & .30 & 99.70 \\
\hline 3.602 & .00 & .00 & 52.30 & 42.70 & 100.00 & .00 & & & & & & & \\
\hline
\end{tabular}

complex $\mathbf{1}$, out of three water molecules, one water molecule is in axial position and other two water molecules are in equatorial positions. Interestingly, fourth water molecule coordinate as $\mathrm{O}-\mathrm{H}$ (hydroxyl group) through hydrogen bonding (distance $1.573 \AA$ ) with the chain hydroxyl hydrogen of L-ascorbic acid. On the other hand, in complex 2 , one water molecule is in the axial position and other one is in an equatorial position with different bond distances. Square pyramidal geometry of both the complexes are interesting because, when we tried to optimize their octahedral geometry by considering four water molecules and one ascorbic acid as a bidentate chelate, it automatically transformed to square pyramidal instead of expected optimized octahedral geometry. It might be due to the property of either bidentate chelating capacity or the inherent property of $\mathrm{Cu}$ (II) ion itself towards L-ascorbic acid. To confirm the square pyramidal geometry, $\mathrm{Cu}(\mathrm{II})$ with three bidentate ascorbic acid was considered for optimization, which also give square pyramidal structure chelated by bidentate centres in equatorial position and one ligand remains in axial position as monodentate ligand. It reveals that bidentate ascorbic acid does not always prefer to coordinate as a bidentate donor. It prefers a particular geometry depending on the nature of the metal centre, stable ring structure (preferably five-membered) as well as the bite angle of the chelating agent. We have tried to calculate the stability constant of $\mathrm{ML}_{3}$ complex but its calculated value was too low and corresponding species percentage become below $10 \%$ which is excluded from the data and is not shown in the species diagram.

In case of the $\mathrm{Ni}(\mathrm{II})$ complexes, $\left[\mathrm{Ni}(\mathrm{L}-\mathrm{asa})\left(\mathrm{H}_{2} \mathrm{O}\right)_{2}\right] \mathbf{4}$ (species $\mathrm{ML}$ ), $\left[\mathrm{Ni}(\mathrm{L}-\mathrm{asa})_{2}\right]^{2-} \mathbf{5}$ (species $\mathrm{ML}_{2}$ ) and $\left[\mathrm{Ni}(\mathrm{L} \text {-asa) })_{3}\right]^{2-} \mathbf{6}$ (species $\mathrm{ML}_{3}$ ) show square planar geometry. In complex 4, L-ascorbic acid acts as a bidentate chelate and two aqua molecules coordinate almost in square planar geometry, whereas in complex 5 two ascorbic acid molecules chelate from opposite sides and forms a square planar complex. Unlike complexes 4 and 5, two ascorbate moieties chelate as mono-dentate and another one as bidentate chelate and ultimately form square planar in complex 6 in Fig. 3.

In order to provide a better understanding of experimental results, theoretical investigation like optimization of all complexes 1-6 (coordinates of all the optimized complexes are given in supplementary material) and HOMO-LUMO energy calculation were performed. HOMO-LUMO energy calculation is significant to interpret their further reactivity in biological system with other bioactive molecules, which might be assessed from their electronic structure and the HOMO-LUMO energy difference of complexes. In case $\mathrm{Cu}(\mathrm{II})$ complexes 1-3, HOMOLUMO energy difference (Fig. 4) in complex $\mathbf{1}$ is maximum and minimum in case of complex 3 , which is probably due to steric effect of the three bulky chelating ligands. Complex 2 is stabilized through two strong hydrogen bonds and corresponding HOMO-LUMO energy difference is comparatively more than 

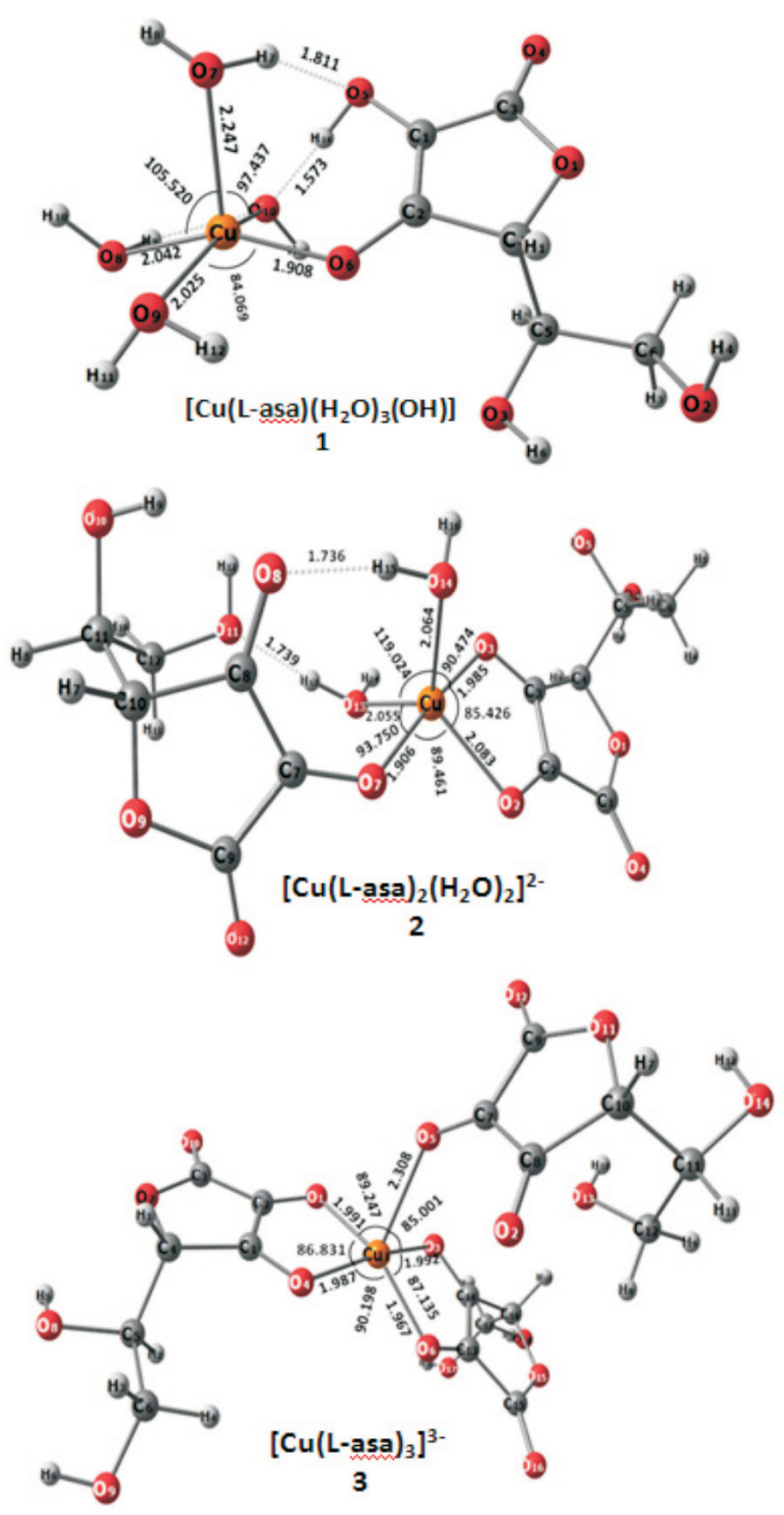
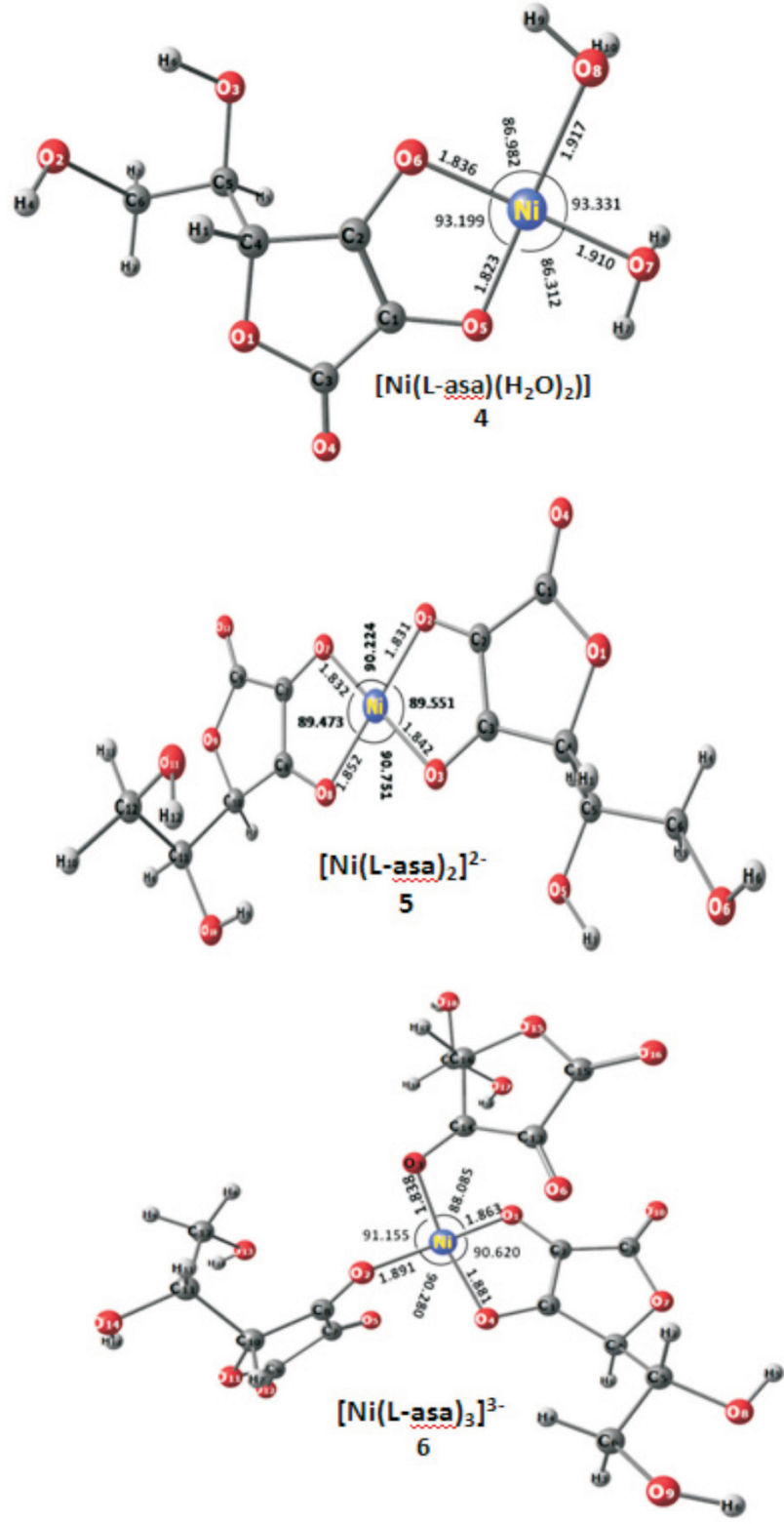

Figure 3 Different optimized structures of $\mathrm{Cu}(\mathrm{II})$ and $\mathrm{Ni}(\mathrm{II})$ complexes with L-ascorbic acid, their corresponding structural geometry, bond lengths and bonds angles.

complex 3. HOMO-LUMO frontier molecular orbitals and energy gap (Fig. 5) among the Ni(II) complexes 4-6, reveal that energy difference is maximum in case of complex 4 and minimum in case of complex 5 . No hydrogen bonding is observed in $\mathrm{Ni}(\mathrm{II})$ complexes 4-6. Complex 5 becomes less stable due to steric effect compared to the other two square planar nickel complexes 4 and 6.

\subsection{Reactivity Parameter}

The reactivity of the proposed complexes can be predicted by evaluating the values of important properties such as electron affinity (A), electrophilicity index $(\omega)$, chemical hardness $(\eta)$, ionization potential $(I)$, electro negativity $(\chi)$, chemical potential $(\mu)$.The absolute values of the HOMO and LUMO are correspondent to the ionization potential (I) and electron affinity (A), respectively. ${ }^{23}$ From HOMO-LUMO energy difference, chemical hardness can be determined by the given equation (10)

$\eta=(I-\mathrm{A}) / 2=\left(\mathrm{E}_{\text {LUмо }}-\mathrm{E}_{\text {номо }}\right) / 2$

Increase in the HOMO-LUMO energy difference the complex will be harder and less reactive in nature. ${ }^{24}$ Chemical potential implies as the negative value of electronegativity $y^{25}$ and can be shown by the following equation (11)

$$
\mu=-\chi=-[(I+\mathrm{A}) / 2]
$$

Increase in the chemical potential enhances the reactivity of the complex. Similarly, electrophilicity index of a complex can be evaluated from the chemical hardness, chemical potential and electronegativity from given equation (12).

$$
\omega=\left(\mu^{2} / 2 \eta\right)=(-\chi)^{2} / 2 \eta
$$

Electrophilicity index signifies the stability of a species by accepting a spare electron from its chemical environment. All these calculated values of the mentioned properties for the complexes are listed in Table 5. The higher HOMO-LUMO energy difference of $\mathrm{Ni}(\mathrm{II})$ and $\mathrm{Cu}(\mathrm{II})$ complexes signify that the complex is harder and thus less reactive. Thus, the investigation of several properties of these $\mathrm{Cu}(\mathrm{II})$ and $\mathrm{Ni}$ (II) complexes are included in this current study to assist in understanding their drug reservoir property. 


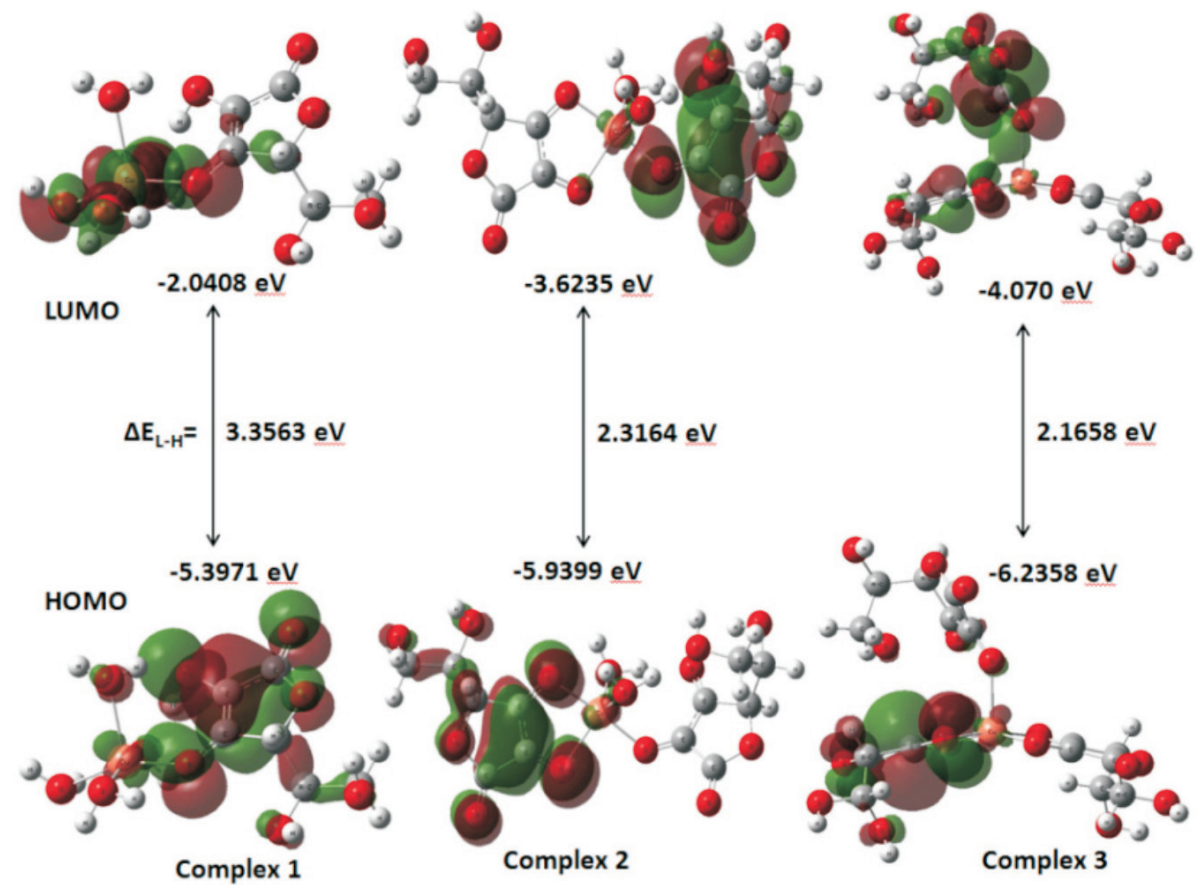

Figure 4 HOMO-LUMO energy diagram of $\mathrm{Cu}$ (II) complexes 1-3.
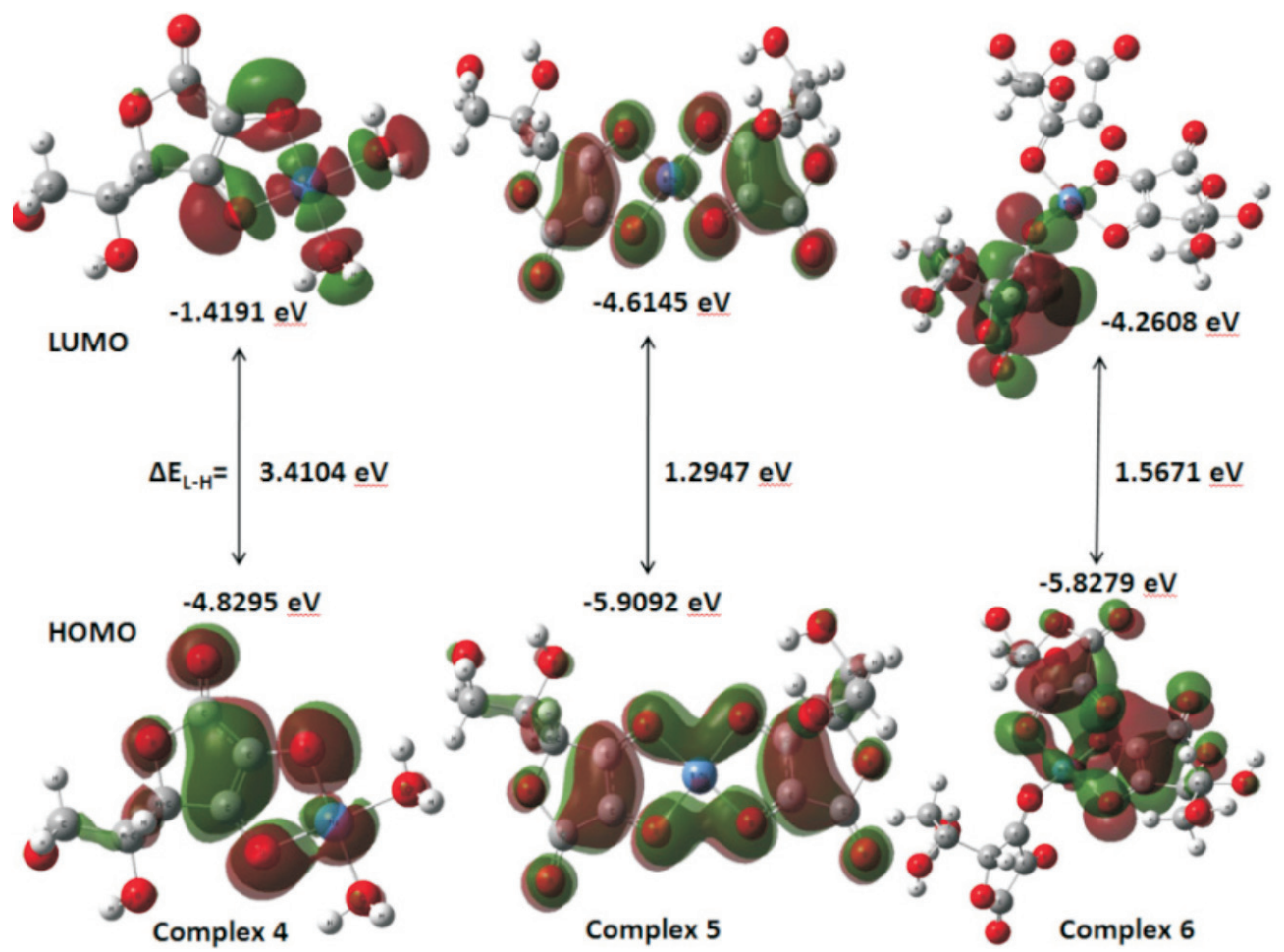

Figure 5 HOMO-LUMO energy diagram of $\mathrm{Ni}(\mathrm{II})$ complexes 4-6.

Table 5 Values of some physical properties of the complexes.

\begin{tabular}{|c|c|c|c|c|c|c|}
\hline Parameters & Complex 1 & Complex 2 & Complex 3 & Complex 4 & Complex 5 & Complex 6 \\
\hline LUMO Energy/eV & -2.0408 & -3.6235 & -4.070 & -1.4191 & -4.6145 & -4.2608 \\
\hline HOMO Energy/eV & -5.3971 & -5.9399 & -6.2358 & -4.8295 & -5.9092 & -5.8279 \\
\hline$\Delta_{\text {LUMO-номо }} / \mathrm{eV}$ & 3.3563 & 2.3164 & 2.1658 & 3.4104 & 1.2947 & 1.5671 \\
\hline Ionization potential/I & 5.3971 & 5.9399 & 6.2358 & 4.8295 & 5.9092 & 5.8279 \\
\hline Electron affinity/A & 2.0408 & 3.6235 & 4.070 & 1.4191 & 4.6145 & 4.2608 \\
\hline Chemical hardness $/ \eta$ & 1.6782 & 1.1582 & 1.0829 & 1.7052 & 0.6474 & 0.7836 \\
\hline Electronegativity $/ \chi$ & 3.7190 & 4.7817 & 5.1529 & 3.1243 & 5.2619 & 5.0444 \\
\hline Chemical potential $/ \mu$ & -3.7190 & -4.7817 & -5.1529 & -3.1243 & -5.2619 & -5.0444 \\
\hline Electrophilicity index $/ \omega$ & 4.1208 & 9.8708 & 12.2598 & 2.8622 & 21.3837 & 16.2366 \\
\hline
\end{tabular}




\section{Conclusions}

L-ascorbic acid exists as $\mathrm{LH}_{2}, \mathrm{LH}^{-}$and $\mathrm{L}^{2-}$ (protonated and deprotonated) species in aqueous medium and form metal chelates with $\mathrm{Cu}(\mathrm{II})$ and $\mathrm{Ni}(\mathrm{II})$ as $\mathrm{MLH}_{2}, \mathrm{MLH}$ and $\mathrm{ML}_{2}$ in the $\mathrm{pH}$ range $2.0-12.5$. These complexes have reasonably stable with a definite percentage of particular species within this $\mathrm{pH}$ range. $\mathrm{No} \mathrm{ML}_{3}$ type of $\mathrm{Cu}$ (II) or $\mathrm{Ni}$ (II) complex species with L-ascorbate was found in experimental species diagram. $\mathrm{Cu}(\mathrm{II})$ complexes 1-3 exist as square pyramidal geometry, whereas $\mathrm{Ni}(\mathrm{II})$ complexes $\mathbf{4}-\mathbf{6}$ are square planar. The stability order of $\mathrm{Cu}$ (II) complexes is $\mathbf{1}>\mathbf{2}>\mathbf{3}$, which is due to stabilization through hydrogen bonding in case of complexes 1 and 2. Steric repulsion among the bulky three ligands might be the reason of lower stability in complex 3 . Unlike $\mathrm{Cu}(\mathrm{II})$ complex, stability order of $\mathrm{Ni}$ (II) complexes is quite different and the order is $\mathbf{1}>\mathbf{3}>\mathbf{2}$, due to steric repulsion between two bidentate chelating ligands and ring strain in the square planar geometry. HOMO-LUMO energy difference also confirms and supports the stability order of $\mathrm{Cu}(\mathrm{II})$ complexes $\mathbf{1 - 3}$. In the case of $\mathrm{Ni}(\mathrm{II})$ complexes, HOMO-LUMO energy gap also reveals the proper order of stability. The reactivity parameters, which are the outcome of this work reveals significant physical properties for prediction of their biological importance.

\section{Acknowledgements}

The authors are thankful to the National Institute of Technology Durgapur, Durgapur-713209, Department of Science and Technology (DST-SERB), (Project No. EEQ/2017/000077), CSIR-HRDG (Project No. 01(2946)/18/EMR-II), DST-FIST (Project No. SR/FST/CSI-267/2015) Government of India and DHESTBT, Govt. of West Bengal (Project No. BT/ST/P/S\&T/2G$44 / 2017$ for providing the projects and financial support for carrying out this work. We are grateful to the reviewers for their valuable suggestions.

\section{${ }^{5}$ ORCID iDs}

S. Mukherjee:

W. Linert :

S. Ch. Moi

orcid.org/0000-0002-3534-8483

orcid.org/0000-0002-2061-0602 orcid.org/0000-0002-7177-0163

\section{References}

1 C. Harford and B. Sarkar, Amino terminal Cu(II)- and Ni(II)-binding (ATCUN) motif of proteins and peptides:? Metal binding, DNA cleavage and other properties, Acc. Chem. Res., 1997, 30(3), 123-130.

2 R. Cammack and M.N. Hughes, Nickel enzymes and cofactors, Encyclopaedia of Inorganic Chemistry, vol. 5, Wiley, New York, 1994, 2384-2391

3 N.E. Dixon, C. Gazzola, R.L. Blakeley and B. Zerner, Jack bean urease, (EC 3.5.1.5). Metallo enzyme. Simple biological role for nickel, J. Am Chem. Soc. 1975, 97(14), 4131-4133.

4 P.M. May, P.W. Linder and D.R. Williams, Computer simulation of metal-ion equilibria in biofluids: models for the low-molecularweight complex distribution of calcium(II), magnesium(II), manganese(II), iron(III), copper(II), zinc(II) and lead(II) ions in human blood plasma, J. Chem. Soc. Dalton Trans., 1977, 588-595.

5 G.E. Jackson, P.M. May and D.R. Williams, Metal-ligand complexes involved in rheumatoid arthritis-VI: computer models simulating the low molecular weight complexes present in blood plasma for normal and arthritic individuals, J. Inorg. Nucl. Chem., 1978, 40, $1227-1234$

6 G. Berthon, B. Hacht, M.J. Blais and P.M. May, Copper-histidine ternary complex equilibria with glutamine, asparagine and serine.
The implications for computer-simulated distributions of copper(II) in blood plasma, Inorg. Chim. Acta, 1986, 125, 219-227.

7 M.J. Barnes, Function of ascorbic acid in collagen metabolism, Ann. NY Acad. Sci., 1975, 258, 264-277.

8 B.M. Tolbert, M. Downing and R.W. Carlson, Chemistry and metabolism of ascorbic acid and ascorbate sulphate, Ann. NY Acad. Sci., 1975, $258,48-69$.

9 B. Halliwell and J.M.C. Gutteridge, Free Radicals in Biology and Medicine, Oxford University Press, Oxford, 1999.

10 T.L. Duarte and J. Lunec, When is an antioxidant not an antioxidant? A review of novel actions and reactions of vitamin C, Free Rad. Res., 2005, 39(7), 671-686.

11 A. Haciserki, An overview of ascorbic acid biochemistry functions. AnkaraEcz. Fak. Derg, 2009, 38(3), 233-255.

12 A.D. Gupta, A.M. Patil, J.G. Ambekar, S.N. Das, S.A. Dhundasi and K.K. Das, L-ascorbic acid protects the antioxidant defense system in nickel-exposed albino rat lung tissue, J. Basic Clin. Physiol. Pharmacol., 2006, 17(2), 87-100.

13 A.F. Kolodziej, The Chemistry of Nickel-Containing Enzymes, Prog. Inorg. Chem., (K.D. Karlin, ed.), Wiley, NewYork, 1994, 41, 493-597.

14 M.J. Frisch, G.W. Trucks, H.B. Schlegel, G.E. Scuseria, M.A. Robb, J.R. Cheeseman, G. Scalmani, V. Barone, B. Mennucci, G.A. Petersson, H. Nakatsuji, M. Caricato, X. Li, H.P. Hratchian, A.F. Izmaylov, J. Bloino, G. Zheng, J.L. Sonnenberg, M. Hada, M. Ehara, K. Toyota, R. Fukuda, J. Hasegawa, M. Ishida, T. Nakajima, Y. Honda, O. Kitao, H. Nakai, T. Vreven, J.A. Montgomery, Jr., J.E. Peralta, F. Ogliaro, M. Bearpark, J.J. Heyd, E. Brothers, K.N. Kudin, V.N. Staroverov, R. Kobayashi, J. Normand, K. Raghavachari, A. Rendell, J.C. Burant, S.S. Iyengar, J. Tomasi, M. Cossi, N. Rega, J.M. Millam, M. Klene, J.E. Knox, J.B. Cross, V. Bakken, C. Adamo, J. Jaramillo, R. Gomperts, R.E. Stratmann, O. Yazyev, A.J. Austin, R. Cammi, C. Pomelli, J.W. Ochterski, R.L. Martin, K. Morokuma, V.G. Zakrzewski, G.A. Voth, P. Salvador, J.J. Dannenberg, S. Dapprich, A.D. Daniels, Ö. Farkas, J.B. Foresman, J.V. Ortiz, J. Cioslowski and D.J. Fox, Gaussian, Inc., Wallingford CT, Gaussian 09 (2009) Revision D.01.

15 M.S. Babu, G.N. Rao, K.V. Ramana and M.S.P. Rao, Computer augmented speciation studies of cobalt(II), copper(II) and zinc(II) complexes of L-glutamic acid in water-urea mixtures, Indian J. Chem., 2001, A 40, 1334-1338.

16 G.N. Rao, Complex Equilibria of Some Biologically Important Metal Ions in Aquo-organic Media, Ph.D. thesis, Andhra University, Visakhapatanam, India, 1989

17 P. Gans, A. Sabatini and A. Vacca, An improved computer program for the computation of formation constants from potentiometric data, Inorg. Chim. Acta, 1976, 18, 237-239

18 G.N. Rao and S.R. Rao, A critical examination of computer programs in complex equilibria by pH metry, J. Indian Council Chem., 1992, 8, 12-28.

19 B.B.V. Sailaja, T. Kebede, G.N. Rao and M.S.P. Rao, Effect of denaturants on the speciation of dicarboxylic acids: uranium (VI) complexes of oxalic acid in micellar media, J. Indian Chem. Soc., 2002, 79, 583-586.

20 E.P. Serjeant and B. Dempsey, Ionization Constants of Organic Acids in Aqueous Solution, Pergamon Press, Oxford, New York, 1979.

21 P. Bhushanavathi and G.N. Rao, Speciation studies of $\mathrm{Co}(\mathrm{II}), \mathrm{Ni}(\mathrm{II})$ and $\mathrm{Cu}(\mathrm{II})$ complexes of L-valine in acetonitrile-water mixtures, Chem. Speciat. Bioavailab., 2013, 25, 258-264.

22 V.S.S. Rao, P.S. Rao, B. Srikanth, C.K. Sastry and G.N. Rao, Speciation of binary complexes of $\mathrm{Co}(\mathrm{II}), \mathrm{Ni}(\mathrm{II}), \mathrm{Cu}$ (II) and $\mathrm{Zn}$ (II) with L-aspartic acid in anionic, cationic and neutral micellar medium, Chem. Speciat. Bioavailab., 2009, 21, 71-80.

23 P.K. Chattaraj and B. Maiti, HSAB principle applied to the time evolution of chemical reactions, J. Am. Chem. Soc., 2003, 125, 2705-2710.

24 R.G. Parr and R.G. Pearson, Absolute hardness: companion parameter to absolute electronegativity, J. Am. Chem. Soc., 1983, 105(26), 7512-7516.

25 I.M. Wekesa and D. Jaganyi, Kinetic and mechanistic studies of 1,3-bis(2-pyridylimino) isoindolate $\mathrm{Pt}(\mathrm{II})$ derivatives. Experimental and new computational approach, Dalton Trans., 2014, 43, 2549-2558. 


\section{Supplementary material to:}

S. Mahata, I. Mitra, S. Mukherjee, V. Pera Reddy B., G. Kr. Ghosh, W. Linert and S. Ch. Moi, Speciation Study of L-ascorbic Acid and its Chelated $\mathrm{Cu}(\mathrm{II})$ \& Ni(II) Complex: an Experimental and Theoretical Model of Complex Formation,

S. Afr. J. Chem., 2019, 72, 229-236. 


\section{Cartesian coordinates of the optimized structures}

Table S1 Cartesian coordinates of complex $1\left[\mathrm{Cu}(\mathrm{L}-\mathrm{asa})\left(\mathrm{H}_{2} \mathrm{O}\right)_{3}(\mathrm{OH})\right]$.

Optimized at B3LYP/lanl2dz/6-31g(d) level of theory

\begin{tabular}{lrrr}
$\mathrm{C}$ & 0.40992900 & 1.58760300 & -0.02054500 \\
$\mathrm{C}$ & 0.54942300 & 0.23934200 & 0.19159400 \\
$\mathrm{C}$ & 1.69038000 & 2.23801100 & 0.11180700 \\
$\mathrm{O}$ & 2.64723800 & 1.27396300 & 0.40332400 \\
$\mathrm{C}$ & 2.02870300 & -0.02946200 & 0.40697500 \\
$\mathrm{C}$ & 2.70141800 & -0.89153400 & -0.68789700 \\
$\mathrm{H}$ & 2.19624900 & -0.48788100 & 1.39024500 \\
$\mathrm{C}$ & 4.22591600 & -0.97002200 & -0.51680800 \\
$\mathrm{O}$ & 4.55579600 & -1.84382500 & 0.57064300 \\
$\mathrm{H}$ & 4.66529500 & 0.02374900 & -0.38716100 \\
$\mathrm{H}$ & 4.65421200 & -1.43210700 & -1.41109600 \\
$\mathrm{H}$ & 4.50769300 & -1.33625900 & 1.39621700 \\
$\mathrm{O}$ & 2.17274900 & -2.20851200 & -0.69133300 \\
$\mathrm{H}$ & 2.47095600 & -0.43803400 & -1.65921500 \\
$\mathrm{H}$ & 2.69316700 & -2.68217300 & -0.01431700 \\
$\mathrm{O}$ & 2.00661500 & 3.41353200 & 0.02649700 \\
$\mathrm{O}$ & -0.74105600 & 2.30577700 & -0.26284900 \\
$\mathrm{O}$ & -0.32173300 & -0.72191500 & 0.22443400 \\
$\mathrm{Cu}$ & -2.19788800 & -0.48323000 & -0.02730300 \\
$\mathrm{O}$ & -2.50382600 & 1.16300200 & 1.47180300 \\
$\mathrm{H}$ & -1.92066600 & 1.82559300 & 1.02440800 \\
$\mathrm{H}$ & -3.38120900 & 1.57608900 & 1.51943400 \\
$\mathrm{O}$ & -4.05638000 & -0.90917700 & -0.75789800 \\
$\mathrm{H}$ & -3.90286800 & -0.30169200 & -1.51699200 \\
$\mathrm{H}$ & -4.83868300 & -0.57068400 & -0.28833500 \\
$\mathrm{O}$ & -2.35402500 & -2.07931800 & 1.20853200 \\
$\mathrm{H}$ & -2.83052000 & -2.83029000 & 0.81529300 \\
$\mathrm{H}$ & -1.43121500 & -2.37050300 & 1.32522500 \\
$\mathrm{O}$ & -2.14752300 & 0.61009500 & -1.58744500 \\
$\mathrm{H}$ & -1.54376900 & 0.20994900 & -2.23398100 \\
$\mathrm{H}$ & -1.29733500 & 1.75530600 & -0.92436400 \\
& & & \\
\hline
\end{tabular}

Table S2 Cartesian coordinates of complex $2\left[\mathrm{Cu}(\mathrm{L}-\mathrm{asa})_{2}\left(\mathrm{H}_{2} \mathrm{O}\right)_{2}\right]^{2-}$.

Optimized at B3LYP/lanl2dz/6-31g(d) level of theory

$\begin{array}{llll}\text { C } & -3.73466300 & -2.12685100 & 0.04396800\end{array}$

$\begin{array}{llll}\text { O } & -4.67692700 & -1.17436900 & 0.36084400\end{array}$

$\begin{array}{llll}\text { C } & -2.42530500 & -1.44227700 & -0.02929300\end{array}$

$\begin{array}{llll}\text { C } & -2.63324400 & -0.07088100 & 0.25188600\end{array}$

$\begin{array}{lrrr}\text { C } & -4.09939700 & 0.15852300 & 0.49032500\end{array}$

$\begin{array}{llll}\text { O } & -1.26610700 & -1.91808000 & -0.27629600\end{array}$

$\begin{array}{llll}\text { O } & -1.66841200 & 0.75572000 & 0.28021100\end{array}$

$\begin{array}{llll}\text { C } & -4.77876000 & 1.11328700 & -0.52190200\end{array}$

$\mathrm{H} \quad-4.28930500 \quad 0.50748200 \quad 1.51175300$

$\begin{array}{lrrr}\text { C } & -6.29877500 & 1.19107100 & -0.31764300\end{array}$

$\begin{array}{llll}\text { O } & -4.02746100 & -3.28974700 & -0.12035100\end{array}$

$\begin{array}{llll}\text { O } & -4.21586200 & 2.40468800 & -0.39027400\end{array}$

$\mathrm{H} \quad-4.56443600 \quad 0.75329100 \quad-1.53405600$

$\begin{array}{llll}\mathrm{H} & -4.71667600 & 2.82181600 & 0.33768100\end{array}$

O $\quad-6.59149100 \quad 1.95813900 \quad 0.85406500$

$\begin{array}{llll}\mathrm{H} & -6.74975000 & 0.19466900 & -0.27918300\end{array}$

$\mathrm{H} \quad-6.72963700 \quad 1.74026500 \quad-1.15979500$

$\mathrm{H} \quad-6.62295900 \quad 1.36091200 \quad 1.61785200$

$\begin{array}{llll}\mathrm{Cu} & -0.01794200 & -0.25395900 & -0.16346500\end{array}$

$\begin{array}{llll}\mathrm{O} & 1.46746100 & -1.36006400 & -0.61284300\end{array}$

$\begin{array}{llll}\text { O } & 2.97435100 & 1.05314700 & -1.71292200\end{array}$

$\begin{array}{llll}\text { C } & 2.70202500 & -1.04650700 & -0.50586300\end{array}$

$\begin{array}{llll}\text { C } & 3.40174700 & 0.09438700 & -1.03219100\end{array}$

$\begin{array}{llll}C & 3.69487200 & -1.87522300 & 0.22566800\end{array}$

$\begin{array}{llll}\text { O } & 4.91959900 & -1.25645200 & 0.16916900\end{array}$

$\begin{array}{llll}\text { C } & 4.84250200 & -0.01892200 & -0.57355000\end{array}$

$\begin{array}{llll}\text { C } & 5.29784900 & 1.17780900 & 0.29528600\end{array}$

H $\quad 5.51282100 \quad-0.09559600 \quad-1.43579700$

$\begin{array}{llll}\text { C } & 4.55349000 & 1.31431200 & 1.62680500\end{array}$

$\begin{array}{llll}\text { O } & 5.18730500 & 2.37397000 & -0.46932700\end{array}$

$\mathrm{H} \quad 6.35950400 \quad 1.03357700 \quad 0.52757900$

$\mathrm{H} \quad 4.41008900 \quad 2.28623800 \quad-1.05625100$

$\begin{array}{llll}\mathrm{O} & 3.17459500 & 1.66115400 & 1.44895400\end{array}$

$\begin{array}{llll}\mathrm{H} & 5.05328600 & 2.08185400 & 2.22903100\end{array}$

$\begin{array}{llll}\mathrm{H} & 4.56872000 & 0.37458300 & 2.18267600\end{array}$

H $\quad 3.13528500 \quad 2.52409400 \quad 1.00349600$

$\begin{array}{llll}\mathrm{O} & 3.53182800 & -2.92438000 & 0.80691800\end{array}$

$\begin{array}{llll}\text { O } & 0.79398600 & 0.33990300 & 1.62868800\end{array}$

$\begin{array}{llll}\mathrm{H} & 1.67464600 & 0.79564200 & 1.61014600\end{array}$

$\begin{array}{llll}\mathrm{H} & 0.19257300 & 0.94180400 & 2.09782700\end{array}$

$\begin{array}{llll}\text { O } & 0.27351300 & 0.92286300 & -1.83382500\end{array}$

$\mathrm{H} \quad 1.25344200 \quad 1.04896600 \quad-1.94493200$

$\begin{array}{llll}\mathrm{H} & -0.11235400 & 1.81093300 & -1.75259900\end{array}$ 
Table S3 Cartesian coordinates of complex $3\left[\mathrm{Cu}(\mathrm{L}-\mathrm{asa})_{4}\right]^{2-}$.

Optimized at B3LYP/lanl2dz/6-31g(d) level of theory

\begin{tabular}{lrrr}
$\mathrm{Cu}$ & 0.65296200 & 0.19732600 & -0.30217200 \\
$\mathrm{O}$ & 1.79212800 & 0.04222000 & -1.92764800 \\
$\mathrm{O}$ & -1.24958700 & -2.09493200 & 1.89850800 \\
$\mathrm{O}$ & -0.74445700 & 1.20003800 & -1.30685200 \\
$\mathrm{O}$ & 2.22178400 & -0.45888300 & 0.72539000 \\
$\mathrm{O}$ & -0.50404400 & -1.68523900 & -0.97055800 \\
$\mathrm{O}$ & -0.09816300 & 0.98694400 & 1.33570400 \\
$\mathrm{C}$ & 3.15300100 & -0.60381600 & -0.12559200 \\
$\mathrm{C}$ & 2.93316500 & -0.34947800 & -1.49852500 \\
$\mathrm{C}$ & 4.19356700 & -0.61466600 & -2.22599300 \\
$\mathrm{O}$ & 5.12118600 & -1.01338000 & -1.29052000 \\
$\mathrm{C}$ & 4.58121900 & -1.02717100 & 0.06874700 \\
$\mathrm{C}$ & 5.44700900 & -0.09763600 & 0.93658100 \\
$\mathrm{H}$ & 4.65824600 & -2.05597300 & 0.43681300 \\
$\mathrm{O}$ & 6.80376500 & -0.52184600 & 0.88491100 \\
$\mathrm{C}$ & 5.05644400 & -0.13173000 & 2.41412900 \\
$\mathrm{H}$ & 5.34963800 & 0.93045200 & 0.56108400 \\
$\mathrm{O}$ & 5.90127300 & 0.72736100 & 3.16310800 \\
$\mathrm{H}$ & 5.11583800 & -1.16955000 & 2.77802800 \\
$\mathrm{H}$ & 4.03037000 & 0.22009500 & 2.54661200 \\
$\mathrm{H}$ & 7.14639100 & -0.32781100 & -0.00276100 \\
$\mathrm{H}$ & 6.80888700 & 0.48503800 & 2.90968500 \\
$\mathrm{O}$ & 4.45700500 & -0.53070500 & -3.40276900 \\
$\mathrm{C}$ & -1.46897700 & -2.26893200 & -0.52837100 \\
$\mathrm{C}$ & -1.87335700 & -2.46301700 & 0.93137700 \\
$\mathrm{C}$ & -2.52141000 & -3.00512000 & -1.35432300 \\
$\mathrm{O}$ & -3.43048500 & -3.53812700 & -0.50563800 \\
$\mathrm{C}$ & -3.19965200 & -3.19796100 & 0.90360100 \\
$\mathrm{O}$ & -2.56142600 & -3.13043500 & -2.54912100 \\
$\mathrm{C}$ & -4.41043700 & -2.36101900 & 1.41066600 \\
$\mathrm{H}$ & -3.14514600 & -4.14414000 & 1.44614400 \\
$\mathrm{C}$ & -4.24746400 & -0.86268200 & 1.09123600 \\
$\mathrm{O}$ & -3.53985800 & -0.61401700 & -0.13660800 \\
$\mathrm{H}$ & -3.64395900 & -0.39575900 & 1.87334600 \\
$\mathrm{H}$ & -5.23226700 & -0.38648200 & 1.08158700 \\
$\mathrm{H}$ & -4.16661100 & -0.61567600 & -0.87932300 \\
$\mathrm{O}$ & -5.61179700 & -2.93588900 & 0.93845400 \\
$\mathrm{H}$ & -4.44343900 & -2.46277100 & 2.49959900 \\
$\mathrm{H}$ & -5.55019000 & -3.02212700 & -0.02829100 \\
$\mathrm{C}$ & -1.06486300 & 1.73379000 & 0.94217100 \\
$\mathrm{C}$ & -1.39891400 & 1.83191700 & -0.42419400 \\
$\mathrm{C}$ & -1.99275500 & 2.59271800 & 1.70729700 \\
$\mathrm{O}$ & -2.86158500 & 3.15330300 & 0.80231300 \\
$\mathrm{C}$ & -2.56212700 & 2.77205900 & -0.57021900 \\
$\mathrm{O}$ & -2.06628000 & 2.81117500 & 2.89469300 \\
$\mathrm{C}$ & -2.22880100 & 4.01423300 & -1.40139800 \\
$\mathrm{O}$ & -3.44626800 & 2.27770800 & -0.98142700 \\
$\mathrm{O}$ & -3.37464000 & 4.62434100 & -0.79367700 \\
& -1.97609500 & -1.40745600 \\
& 5.480000 & 5.20994200 & -2.1 .44104000 \\
& & \\
\hline
\end{tabular}

Table S4 Cartesian coordinates of complex 4 [Ni(L-asa) $\left.\left(\mathrm{H}_{2} \mathrm{O}\right)_{2}\right]$.

Optimized at B3LYP/lanl2dz/6-31g(d) level of theory

$\begin{array}{llll}\text { C } & 0.30044600 & 1.22277400 & -0.03984300\end{array}$

$\begin{array}{llll}\text { C } & -0.21580000 & -0.00916300 & -0.26090200\end{array}$

C $\quad-0.75946000 \quad 2.19795900 \quad-0.04669500$

$\begin{array}{llll}\text { O } & -1.95609400 & 1.50591600 & -0.28472100\end{array}$

C $\quad-1.70590500 \quad 0.08087500 \quad-0.41562900$

$\begin{array}{llll}\text { C } & -2.52996600 & -0.67252300 & 0.64945900\end{array}$

H $\quad-2.03851500 \quad-0.22829500 \quad-1.41615800$

$\begin{array}{llll}\text { C } & -4.03564100 & -0.39823300 & 0.54165600\end{array}$

O $\quad-4.58177900 \quad-1.07854300 \quad-0.59581200$

$\begin{array}{llll}\mathrm{H} & -4.24163700 & 0.67652400 & 0.50992500\end{array}$

$\mathrm{H} \quad-4.53500300 \quad-0.82764000 \quad 1.41516700$

$\mathrm{H} \quad-4.44246400 \quad-0.52342800 \quad-1.37944000$

$\begin{array}{llll}\mathrm{O} & -2.30132300 & -2.07007300 & 0.53080300\end{array}$

$\begin{array}{llll}\mathrm{H} & -2.17346200 & -0.35903000 & 1.63752000\end{array}$

$\begin{array}{llll}\mathrm{H} & -2.93257800 & -2.36320200 & -0.15405400\end{array}$

$\begin{array}{llll}\mathrm{O} & -0.77717800 & 3.40986600 & 0.10234800\end{array}$

$\begin{array}{llll}\text { O } & 1.63937900 & 1.35148500 & 0.12995900\end{array}$

$\begin{array}{llll}\text { O } & 0.59758800 & -1.05337700 & -0.31452100\end{array}$

$\begin{array}{llll}\text { O } & 4.01107100 & 0.40548300 & 0.16778000\end{array}$

$\mathrm{H} \quad 3.84996800 \quad 1.36202800 \quad 0.27962700$

$\mathrm{H} \quad 4.52914500 \quad 0.13140200 \quad 0.94601500$

$\begin{array}{llll}\text { O } & 2.94463200 & -2.13176500 & -0.24861600\end{array}$

$\mathrm{H} \quad 2.16721000 \quad-2.69348200 \quad-0.42693700$

$\begin{array}{llll}\mathrm{H} & 3.37948800 & -2.52728200 & 0.52842100\end{array}$

$\mathrm{Ni} \quad 2.26805100 \quad-0.35320300 \quad-0.01450500$ 
Table S5 Cartesian coordinates of complex 5 [Ni(L-asa $\left.)_{2}\right]^{2-}$.

Optimized at B3LYP/lanl2dz/6-31g(d) level of theory

$\begin{array}{lrrr}\mathrm{C} & -3.42443600 & -2.04650600 & 0.61611600 \\ \mathrm{O} & -4.30827100 & -0.98765000 & 0.67444100 \\ \mathrm{C} & -2.10909600 & -1.45970400 & 0.31812000 \\ \mathrm{C} & -2.23941200 & -0.08030400 & 0.20859500 \\ \mathrm{C} & -3.67270400 & 0.30267800 & 0.40410700 \\ \mathrm{O} & -0.92674900 & -1.97213800 & 0.16258300 \\ \mathrm{O} & -1.17083500 & 0.59628800 & -0.03098700 \\ \mathrm{C} & -4.34042800 & 0.95930700 & -0.82861800 \\ \mathrm{H} & -3.81492200 & 0.93432900 & 1.28780000 \\ \mathrm{C} & -5.83886400 & 1.21615600 & -0.61119000 \\ \mathrm{O} & -3.77167600 & -3.19056700 & 0.79576300 \\ \mathrm{O} & -3.67996700 & 2.17857600 & -1.10587200 \\ \mathrm{H} & -4.20238100 & 0.29491800 & -1.68815700 \\ \mathrm{H} & -4.11886000 & 2.83753200 & -0.53294600 \\ \mathrm{O} & -6.01568300 & 2.32736700 & 0.27117300 \\ \mathrm{H} & -6.35006500 & 0.31811600 & -0.25055100 \\ \mathrm{H} & -6.27807000 & 1.50958200 & -1.56903800 \\ \mathrm{H} & -6.05736300 & 1.99972200 & 1.18320100 \\ \mathrm{O} & 1.62435200 & -1.77561600 & -0.27577600 \\ \mathrm{O} & 1.40982000 & 0.80012600 & -0.49046300 \\ \mathrm{C} & 2.70236200 & -1.09274400 & -0.49981700 \\ \mathrm{C} & 2.58362600 & 0.28875800 & -0.60513500 \\ \mathrm{C} & 4.11841600 & -1.46296000 & -0.65612200 \\ \mathrm{O} & 4.80405800 & -0.27893500 & -0.85512100 \\ \mathrm{C} & 3.92959700 & 0.89139700 & -0.85754800 \\ \mathrm{C} & 4.39593700 & 1.94236000 & 0.18048300 \\ \mathrm{H} & 3.98484300 & 1.34476600 & -1.85249600 \\ \mathrm{C} & 4.53030100 & 1.39059700 & 1.60050400 \\ \mathrm{O} & 3.51353700 & 3.05264700 & 0.10120800 \\ \mathrm{H} & 5.37692200 & 2.30939000 & -0.13795400 \\ \mathrm{H} & 2.62616300 & 2.75320900 & 0.36572200 \\ \mathrm{O} & 3.29496400 & 0.88321200 & 2.10631600 \\ \mathrm{H} & 4.92631300 & 2.18435400 & 2.24488900 \\ \mathrm{H} & 5.24255300 & 0.56050100 & 1.60622100 \\ \mathrm{H} & 2.79679100 & 1.61809300 & 2.49687500 \\ \mathrm{O} & 4.67449300 & -2.53566200 & -0.63018800 \\ \mathrm{Ni} & 0.23114100 & -0.59071100 & -0.16268400 \\ & & & \\ & & & \\ & & \\ \end{array}$

Table S6 Cartesian coordinates of complex $6\left[\mathrm{Ni}(\mathrm{L}-\mathrm{asa})_{3}\right]^{2-}$

Optimized at B3LYP/lanl2dz/6-31g(d) level of theory

\begin{tabular}{rrrr}
\hline $\mathrm{O}$ & 1.45260700 & 0.38306300 & -1.23542900 \\
$\mathrm{O}$ & -1.79080000 & 0.02215300 & 0.62025900 \\
$\mathrm{O}$ & 0.02782000 & 1.93162500 & 0.24555900 \\
$\mathrm{O}$ & -0.03738500 & -1.68257500 & -0.46081600 \\
$\mathrm{O}$ & -2.48117700 & -0.57703400 & -2.25611900 \\
$\mathrm{O}$ & 2.06597400 & -0.03838500 & 1.38051400 \\
$\mathrm{C}$ & 1.20478700 & -1.87612900 & -0.74441600 \\
$\mathrm{C}$ & 2.00175400 & -0.80373700 & -1.10686400 \\
$\mathrm{C}$ & 3.34966000 & -1.28361400 & -1.40213500 \\
$\mathrm{O}$ & 3.33495800 & -2.65614900 & -1.20677500 \\
$\mathrm{C}$ & 2.01917200 & -3.13547700 & -0.78865600 \\
$\mathrm{C}$ & 2.18722600 & -3.86650900 & 0.55268200 \\
$\mathrm{H}$ & 1.66793500 & -3.83763600 & -1.55299100 \\
$\mathrm{O}$ & 3.12149000 & -4.93130300 & 0.40989800 \\
$\mathrm{C}$ & 0.89297000 & -4.51375100 & 1.04234100 \\
$\mathrm{H}$ & 2.53758300 & -3.14317400 & 1.30199800 \\
$\mathrm{O}$ & 1.11615100 & -5.19321800 & 2.26855500 \\
$\mathrm{H}$ & 0.51740900 & -5.20044000 & 0.26718000 \\
$\mathrm{H}$ & 0.13051600 & -3.75195100 & 1.22383100 \\
$\mathrm{H}$ & 3.99764200 & -4.53945800 & 0.26154300 \\
$\mathrm{H}$ & 1.90367100 & -5.74467500 & 2.11881700 \\
$\mathrm{O}$ & 4.35550800 & -0.69967100 & -1.74238000 \\
$\mathrm{C}$ & -3.21471600 & -0.59817500 & -1.30295700 \\
$\mathrm{C}$ & -2.87828100 & -0.30355100 & 0.15083200 \\
$\mathrm{C}$ & -4.70635800 & -0.95016700 & -1.29072600 \\
$\mathrm{O}$ & -5.15035300 & -0.90058000 & -0.01115800 \\
$\mathrm{C}$ & -4.12898400 & -0.49818300 & 0.95322300 \\
$\mathrm{O}$ & -5.39534600 & -1.23768200 & -2.23073100 \\
$\mathrm{C}$ & -4.63162400 & 0.77570100 & 1.70391900 \\
$\mathrm{H}$ & -4.01268900 & -1.32246600 & 1.66231000 \\
$\mathrm{C}$ & -4.30522900 & 2.05412000 & 0.89443300 \\
$\mathrm{O}$ & -4.10244700 & 1.79124000 & -0.50477900 \\
$\mathrm{H}$ & -3.36411400 & 2.47727800 & 1.25200700 \\
$\mathrm{H}$ & -5.09969200 & 2.78980900 & 1.04505600 \\
$\mathrm{H}$ & -4.93947100 & 1.91153800 & -0.98396800 \\
$\mathrm{O}$ & -5.98923600 & 0.61365400 & 2.04042800 \\
$\mathrm{H}$ & -4.09851700 & 0.82587000 & 2.65710600 \\
$\mathrm{H}$ & -6.49509900 & 0.46905400 & 1.22227500 \\
$\mathrm{C}$ & 2.19125800 & 1.17292600 & 1.14248800 \\
$\mathrm{C}$ & 1.21331000 & 2.13151100 & 0.64181700 \\
$\mathrm{C}$ & 3.43406100 & 1.98609700 & 1.42601000 \\
$\mathrm{O}$ & 3.15945300 & 3.30600400 & 1.23165100 \\
$\mathrm{C}$ & 1.80840600 & 3.51211700 & 0.75347100 \\
$\mathrm{O}$ & 4.51330600 & 1.59360600 & 1.79810000 \\
$\mathrm{C}$ & 1.82825200 & 4.27882900 & -0.57536600 \\
$\mathrm{H}$ & 1.27077300 & 4.10980800 & 1.49757100 \\
$\mathrm{O}$ & 2.67258200 & 3.58476900 & -1.46270400 \\
$\mathrm{O}$ & 2.29034800 & 5.57296600 & -0.28005100 \\
$\mathrm{H}$ & 0.80013300 & 4.30561400 & -0.96213700 \\
$\mathrm{H}$ & 2.22944000 & 6.10418300 & -1.09145000 \\
$\mathrm{H}$ & -0.15313500 & 0.18903900 & -2.36669000 \\
\hline
\end{tabular}

